\title{
SPANXN1 Gene
}

National Cancer Institute

\section{Source}

National Cancer Institute. SPANXN1 Gene. NCI Thesaurus. Code C92985.

This gene may be involved in the maturation of sperm. 